\title{
A Proposed Program to Develop Teaching for Thinking in Pre-service English Language Teachers
}

\author{
Huda U Alwehaibi ${ }^{1}$ \\ ${ }^{1}$ College of Education, Department of Curriculum and Instruction, Princess Noura Bint Abdulraman University, \\ Saudi Arabia \\ Correspondence: Huda U Alwehaibi, College of Education, Department of Curriculum and Instruction, Princess \\ Noura Bint Abdulraman University, P O Box 105938, Riyadh 11656, Saudi Arabia. E-mail: Hudawh@yahoo.com
}

Received: February 29, 2012 Accepted: March 25, 2012 Online Published: July 1, 2012

doi:10.5539/elt.v5n7p53 URL: http://dx.doi.org/10.5539/elt.v5n7p53

This paper has been presented at The International Conference on Education and New Learning Technology, EDULEARN09, in Barcelona, Spain (6-8 July 2009)

\begin{abstract}
Students' thinking is an integral part of English language pedagogy. Teachers need the pedagogical competence to teach thinking effectively. This research suggests a program to develop the teaching skills for thinking of pre-service teachers (fourth-year college students) in the English Department of the Faculty of Education at Princess Noura University in Riyadh, Saudi Arabia. The program aims to provide the knowledge, skills, and experience necessary for preparing teachers of thinking to invite, maintain, and enhance students' thinking in the EFL classroom. A classroom observation checklist was developed to assess teaching for thinking skills, to understand the student teachers progress in developing such skills. The program was pilot tested on five fourth-year student teachers during their field experience. Data analysis and results of the pilot test have shown that the proposed program can be effective in developing the pre-service English language teachers' skills in teaching for thinking.
\end{abstract}

Keywords: methods of TEFL, thinking skills, pre-service teachers, teaching for thinking, classroom observation checklist, teacher training program

\section{Introduction}

In today's age of information, mastery of thinking skills is considered a basic requirement for coping with this rapidly changing world. Learning to think critically and creatively is a lifelong skill with broad applications both inside and outside the classroom. "Thinking is what we do to 'play' the instrument of knowledge. Thinking is what brings knowledge to life, what puts it to work,... what shapes it toward creative products and outcomes" (Perkins, 2008, p. x). Swartz (2001) points out that it is through careful thinking that human beings can make the most of their minds, and through such behaviors that great civilizations are built. The term thinking skills has recently become something of a buzz word in educational circles, and developing the students' potential for thinking critically and creatively has gained prominence and wide popularity around the globe for the promise it holds for effective learning. U.S. schools consider mastery of thinking skills a major goal of instruction in almost all subject areas. Fisher (2007) claims that critical and creative thinking is now widely seen as a basic competency that should be taught, akin to reading and writing.

Developing thinking skills addresses many complex issues in teaching and learning. Swartz, Costa, Beyer, Reagan, and Kallic (2008) and Swartz (2001) claim that teaching skillful thinking not only enhances students' thinking abilities and learning in the content areas but also greatly improves the quality of their lives and their professional work after they leave school. It also improves their self-images and their motivation to learn. Subject-matter learning and thinking skills improvement can each reinforce and contribute to the development of the other in a highly integrated fashion (Prawat, 1991). Beyer (2008) believes that the research showing the effectiveness of teaching thinking skills and the benefits derived from it indicates that such teaching is worth doing. It improves students' academic achievement and their quality of thinking. Hyerle (2000) indicates that the systematic use of thinking maps leads to improvement in test results and quality indicators. Wenglinsky (2000) reported that students of math teachers who studied and taught for higher order thinking skills outperformed students who were not taught these skills. 
Perkins (2008) points out that the idea of teaching thinking is very old but that a fully developed art and craft of teaching it is quite new. Brandt (1984) suggests that a balanced program for the teaching of thinking should include three components: teaching for thinking, teaching of thinking, and teaching about thinking. Costa (2001a) provides an interpretation of each term:

1. Teaching for thinking means that "teachers and administrators examine, monitor and strive to create school and classroom conditions that are conducive to children thinking" (p. 354). This means that the teacher employs various instructional behaviors that would encourage students to use their native intelligence, such as asking thought provoking questions, using cognitive language, and posing problematic situations. It also means that administrators structure a school environment for thinking.

2. Teaching of thinking means instructing students directly in cognitive skills, operations, and dispositions. It includes teaching the steps and strategies of thinking skills, as well as "habituating those attitudes, dispositions, or habits of mind that characterize effective skilful thinkers" (p. 355).

3. Teaching about thinking is composed of four components: brain functioning, metacognition, great thinkers, and epistemic cognition.

Costa explains that the three kinds of teaching mentioned above can offer a well-balanced program.

Martin and Michelli (2001) urge that teaching for thinking must be an important part of U.S. education as the research supports more complex learning and constructivist approaches. Preparing teachers of thinking and teachers for thinking requires incorporating thinking skills in the teacher education curriculum, not only into course work but also into practicum work. Proficiency in thinking skills is a basic requirement for meeting the current accreditation standards for various teacher education programs. Teachers of English to Speakers of Other Languages (TESOL) and the American Council on Teaching of Foreign Languages (ACTFL) are assessed for accreditation by the National Council for Accreditation of Teacher Education (NCATE) in terms of evidence that such programs actively promote various thinking skills. Developing an understanding and use of critical thinking, problem solving, and higher order thinking operations are among the program standards assessed by NCATE. Moreover, learners are required to complete a field experience during which they employ various instructional strategies for developing critical thinking and problem solving (NCATE, 2008).

Therefore, recent trends in teaching English as a foreign or second language (EFL/ESL) have emphasized the importance of promoting thinking as an integral part of English language pedagogy. Research evidence has shown that cognition and language development are closely related, demonstrating that language and thinking competencies shape each other (Rojas, 2001). Such close relationships between language and thinking skills have long been recognized by theorists and educators (Piaget, 1971; Vygotsky, 1962). Incorporating thinking skills instruction into the EFL programs has proved to be successful in a number of studies. Davidson and Dunham (1996) found that college students who received additional training in critical thinking skills scored significantly higher on the Ennis-Weir Critical Thinking Essay Test in EFL classes, compared with a group who received only content-based intensive English instruction. Renner (1996) found that higher order thinking skills promote higher order learning skills, which in turn enable students to reach a higher level of English language proficiency. A study conducted by Sokol, Oget, Sonntag, and Khomenko (2008) showed that high school students working with the thinking approach to language teaching and learning demonstrated a significant increase in their inventive thinking skills in comparison to the control group. Al-Sudies (2005) also reported significant development in skills for teaching writing among pre-service EFL teachers who received instructional training in metacognitive awareness. Such results imply that various thinking skills can be taught and incorporated as part of an academic EFL/ESL program.

\section{Context of the Problem}

Beyer (2001) argues that the primary explanation for poor achievement of students is that most teachers do not teach thinking skills. Although many teachers claim to teach their students how to think indirectly or implicitly in the course of teaching their subjects, most students do not develop the required thinking skills (Fisher, 2007). Several studies have reported lack of knowledge or understanding of thinking skills and of the teaching methods for and successful practice of such skills among school teachers and university professors (Bataineh \& Alazzi, 2009; Innabi \& El Sheikh, 2007; Paul, Elder, \& Bartell, 1997; Stapleton, 2011; Thurman, 2009).

This ignorance about teaching thinking could be attributed to many factors. Although developing thinking skills is essential, it is not typically a significant component of a quality educational program. Martin and Michelli (2001) point out that pre-service teacher education programs have been slow to respond to the need for explicitly preparing teachers of thinking, enabling them to include specific thinking strategies in their teaching. Thurman (2009) also indicates a gap in educational preparedness between high school and college, particularly in teaching critical thinking skills. 
Recently, some teacher education programs in Saudi Arabia have begun systematically to incorporate the dimension of teaching thinking into their curricula by assigning courses that aim to develop the students' thinking skills. However, these programs do not prepare the instructors themselves to teach for thinking. The student teachers in faculties of education are not provided with adequate knowledge and training for teaching thinking skills, either during their methodology courses or in their field experience where they practice actual teaching in schools. What is lacking is adequate training on the teaching behaviors and strategies that stimulate students' thinking, such as incorporating challenging questions and using specific thinking strategies in their teaching.

Teacher education programs need to meet the expectations created by the increasing demand in developing the students' thinking skills and should effectively incorporate teaching for thinking into their curricula. Therefore, this research suggests a program to develop pre-service teachers' skills in teaching for thinking, as well as those of teachers in general. The program's various components constitute an integrative framework for a well developed training program that aims to provide the knowledge, skills, and experience necessary for preparing teachers of thinking in the EFL classroom. This research has also developed a classroom observation checklist of EFL teachers' behaviors that invite, maintain, and enhance students' thinking to be adopted as a basis for evaluating teachers' performance.

\section{Research Questions}

The present study attempted to answer the following questions:

1. What skills in teaching for thinking and the related teaching behaviors should pre-service English language teachers possess?

2. What training program is suggested for pre-service English language teachers to develop their skills in teaching for thinking?

\section{Instrumentation}

\subsection{Classroom Observation Checklist}

The classroom observation checklist developed for this study was designed to point out the skills in teaching for thinking that pre-service English language teachers should possess. It comprises the teaching behaviors that lead to students' thinking. Costa (2001b) claims that certain teacher behaviors invite, maintain, and enhance students' thinking in the classroom, and these fall into four major categories:

- Questioning to challenge students' intellect

- Structuring the classroom for thinking

- Initiating teacher response behaviors

- Modeling with cognitive goals and objectives.

The above-mentioned categories are the foundation of the classroom observation checklist. The researcher listed a number of related teaching behaviors and strategies that invite and enhance student thinking, based on those suggested by Costa (2001b), Field (2001), and Barell (2001), and developed a 5-point scale for rating these behaviors.

\subsubsection{Validity of the Checklist}

The classroom observation checklist was submitted to the examination of five university professors, specialists in curriculum and instruction, for determining its validity. These evaluators were required to determine its appropriateness and congruence with the aims and objectives of the program. Based on their comments and suggestions, some modifications were made.

\subsubsection{Reliability of the Checklist}

To determine the reliability of the checklist, inter-coder agreement checks were conducted using Cooper's Formula (Ary, Jacobs, Razavieh, \& Sorensen, 1996). The researcher and a trained professor simultaneously observed the teaching behaviors of 10 secondary school English language teachers using the observation checklist. Based on the data obtained, Cooper's Formula was used to compute the percentage of agreement between the two observers, which indicates the percentage of reliability of the checklist. The checklist proved to be $80 \%$ reliable. Figure 1 shows the classroom observation checklist.

\subsection{Classroom Observation Checklist for English Language Teachers' Behaviors that Lead to Students' Thinking}

Name of the student teacher:

School: Observer: 
Please mark "X" in the appropriate column for each teacher classroom behavior using the scale of 1 to 5 on the following items:

Table 1. The Classroom Observation Checklist

\begin{tabular}{|c|c|c|c|c|c|}
\hline $\begin{array}{l}\text { Teacher behaviors that invite, maintain and enhance students' } \\
\text { thinking in the classroom }\end{array}$ & $\begin{array}{l}5 \\
\text { Very } \\
\text { Often }\end{array}$ & $\begin{array}{c}4 \\
\text { Often }\end{array}$ & \begin{tabular}{l}
\multicolumn{1}{c}{3} \\
Some-ti \\
mes
\end{tabular} & $\begin{array}{c}2 \\
\text { Seldom }\end{array}$ & $\begin{array}{c}1 \\
\text { Never }\end{array}$ \\
\hline
\end{tabular}

\section{Questioning To Challenge Students' Thinking}

1. Asks open-ended questions

2. Poses questions at higher levels of Bloom's taxonomy

3. Invites students to think hypothetically and creatively (e.g. posing "what if" or "suppose that" questions)

4. Poses problematic situations

5. Asks "Why do you think so?"

6. Encourages students to ask thought provoking questions

7. Encourages students to ask and answer each other's questions

8. Encourages students to apply past knowledge or experience to new situations

9. Poses a homework question or activity that stimulates students' thinking

II. Structuring the Classroom for Thinking

10. Moves around the room

11. Allows students' mobility to practice the language

12. Encourages students' interaction and cooperation

13.Uses different class groupings for different activities

14. Establishes an atmosphere in which thinking is valued

15. Displays creative works of students around the room

16. Reinforces students for responding to open-ended questions

17. Encourages incorrect student responses with supportive comments

18. Uses a variety of visual media (e.g., charts, chalkboard, maps, pictures, gestures) to develop cognitive strategies

19. Provides appropriate evaluation activities

\section{Teacher Response Behaviors}

20. Accepts students' responses without judgment to encourage exploring possibilities

21. Seeks evidence for stated claims by asking students to clarify and justify their responses

22. Allows wait time (at least 10 seconds) for students' answers

before restating or redirecting the question

23. Allows time to consider alternatives/points of view

24. Encourages more than one student to give points of view / solutions

25. Requires students to expand on answers

26. Encourages students to reflect on their thought processes and work orally and in writing

IV. Modeling: Behaving Concurrently with Cognitive Goals and

Objectives

27. Acts as facilitator

28. Uses cognitive language (e.g., compare, analyze, classify,

predict, create) that invites students to think.

29. Shows enthusiasm for challenges and complex tasks requiring

thoughts

30. Uses outlining

31. Presents in a logical and organized way

32. Forms mental images for abstract ideas

33. Uses "if/then" language

34. Uses clear/real examples to facilitate

logical thoughts

35. Transfers cognitive skills to everyday life 


\subsubsection{The Training Program}

To effect curriculum change, teacher change is required (Martin \& Michelli, 2001). Ong (2006) stresses that "the essence of efforts to improve students' thinking is the conceptualization and implementation of a well-developed thinking skills program" (p. 303). To address this demand and for the purpose of the study, a training program was designed to develop pre-service teachers' (fourth-year college students) skill in teaching for thinking at the English department in the Faculty of Education at Princess Noura University in Riyadh. The program consists of various components that constitute a comprehensive integrative framework for a well developed training program. This program, which requires approximately 40 training hours over a period of 10 days to achieve its objectives, is ultimately intended for teachers of EFL at any level or for pre-service EFL teachers who have never studied about thinking or had any training courses about developing thinking skills. The training can be conducted with any number of participants, ranging from five to 20 participants per session.

\subsubsection{Aim and Objectives of the Program}

The program aims to develop pre-service English language teachers' skills in terms of teaching for thinking. By the end of the program, the student teachers will be able to carry out the following objectives:

\section{Define skillful thinking.}

2. Discuss the effective habits of mind when responding to problems.

3. Give examples of the different processes of thinking.

4. Identify thinking skills for the information age and classify them.

5. Practice critical and creative thinking when discussing real world issues.

6. Demonstrate the importance of teaching thinking.

7. Identify the components of a balanced program for teaching thinking.

8. Apply the principles of teaching for thinking in EFL classrooms.

9. Practice the teaching behaviors that invite, maintain, and enhance students' thinking.

10. Ask questions that stimulate students' thinking.

11. Plan lessons according to the framework of teaching for thinking.

12. Carry out lessons in the classroom using various strategies for teaching thinking.

13. Structure an appropriate classroom environment for teaching thinking.

14. Self-assess their lessons in the light of the classroom observation checklist.

15. Use appropriate techniques for assessing growth in students thinking abilities.

\subsubsection{Content of the Program}

The program is composed of six units, each of which highlights different components of teaching thinking, each unit being organized into the following five sections:

- Objectives: Outlines the knowledge and skills the student teachers are expected to acquire

- Content summary: Describes the instructional materials the instructor should cover in the training session

- Activities: Provides opportunities to become active participants and to practice the skills and strategies they have learned

- Evaluation: Determines the extent to which the student teachers have had a successful learning experience

- $\quad$ Resource: Offers websites and related materials.

The units of the program include the following:

Unit 1: The concept of thinking

What is meant by thinking? What is meant by skillful thinking? This portion outlines the necessity of developing thinking and the characteristics of effective thinkers, who employ effective habits of minds.

\section{Unit 2: Skills and processes of thinking}

Basic thinking skills; thinking skills for the information age: critical thinking, creative thinking, and metacognition; the need to apply these thinking operations to real world issues. 
Unit 3: Teaching thinking

Can thinking skills be taught? Can thinking be taught in regular classes? The need to teach thinking; the components of a balanced program for teaching thinking: teaching for thinking, teaching of thinking, and teaching about thinking; principles and practices of teaching for thinking in EFL classrooms.

Unit 4: Teacher behaviors and strategies that enable students' thinking

The major categories of teacher behaviors and strategies that enable students' thinking: questioning, responding, structuring, and modeling; examples of these instructional behaviors and strategies.

Unit 5: Planning lessons to teach for thinking

Employing strategies for teaching thinking (visual techniques, problem solving); classroom environment that enhances students' thinking; the use of instructional media.

Unit 6: Assessing thinking skills

Techniques of assessing teaching for thinking (classroom observation checklist, self-reflection on models of teaching); techniques for assessing growth in students thinking abilities (tests, portfolios, checklists)

\subsubsection{Training Strategies}

Joyce and Showers (1980) have outlined the principles and components of effective development of teachers: presentation of theory, demonstration or modeling of skills, practice, structured feedback, and coaching for application. They stress that if new concepts and strategies are to transfer to classroom teaching, these components need to be combined and built on each other. In order to provide the teachers with the knowledge, experience, and skills in teaching for thinking, the program can be carried out through a set of procedures that involve the use of such components:

\section{Presentation of theoretical background}

Current literature on thinking and the components of teaching thinking are synthesized in a simple framework and presented through a number of strategies, such as lectures, discussion, brainstorming, problem solving, and cooperative learning.

\section{Practicum (field experience)}

Based on the principles and practices of teaching for thinking, the student teachers conduct lessons in an actual classroom, trying out the knowledge and strategies they have learned.

\section{Feedback}

Constructive feedback is provided through careful observation using the classroom observation checklist included in this program. Such feedback gives the student teacher an opportunity to reflect on his or her teaching behaviors.

\section{Coaching}

Coaching as defined by (Routman, 1994) is the "collegial process where support, assistance, and companionship are given along with demonstrations and constructive feedback" (p. 464). In providing such a process to each student teacher, the instructor as a nonjudgmental coach encouragingly guides the teachers in analyzing and interpreting teaching behaviors to acknowledge strengths and address strategies for improvement.

\subsubsection{Evaluation of the Program}

\section{Formative evaluation}

Formative evaluation is an ongoing, descriptive, and non-judgmental process that aims at identifying the program's strengths and weaknesses so that appropriate reinforcements or remediation can be provided. It can be done through the following steps:

a. Observing the students' teaching behaviors

b. Discussing the program with student teachers to gain feedback

c. Giving short tests and tasks to the student teachers

d. Asking and answering questions such as the following:

- Are there indications that the program objectives will be met?

- Are the program topics being taught successfully? 
- Have you identified additional topics that need to be taught?

- $\quad$ Are the training methods appropriate, or do you need to adjust them?

2. Summative evaluation

Summative evaluation is a process that assesses the program's success - the extent to which the completed program has met its aim. It can be done through the following steps:

a. Having the student teachers conduct lessons

b. Observing their teaching behaviors through using the classroom observation checklist

c. Gathering impressions of the student teachers through surveys and interviews

d. Asking and answering questions like the following:

- Did you meet the program objectives?

- Will you need to improve and modify some areas?

- Did you benefit from the program?

The resources used for the program are presented in the Appendix section at the end.

4.2.6 Content Validity of the Program

This training program was submitted to a number of specialists in English language methodology and teaching thinking to determine the content validity, as follows:

1. Is it comprehensive in covering the essential components that constitute a well developed training program?

2. Does it cover the key principles, strategies, and techniques of teaching for thinking?

Some modifications were made to the program according to the comments and suggestions received.

\subsubsection{Pilot Testing of the Program}

A typical pilot test involves conducting a preliminary test of an instrument on a small scale (with 4-5 individuals that have similar characteristics to the target population) to get feedback on whether or not the instrument is likely to work as expected in real situations (Ary, Jacobs, Razavieh, \& Sorensen, 1996). Five pre-service English language teachers engaged in their field experience at a public secondary school in Riyadh were chosen to pilot test the program through the following procedures:

1. The classroom observation checklist (Figure 1) was applied to the subjects of the sample prior to the commencement of the program to observe their teaching behaviors in the English classes. Each student was observed twice, and then the mean score was calculated.

2. Subjects in the sample received training in developing thinking skills in general, and in teaching for thinking in particular, over a period of 10 days ( 40 hours). The researcher carried out the training, using the proposed program.

3. After the students had completed the training program, the classroom observation checklist was applied to the sample twice and the mean score obtained for each student.

4. In an attempt to reveal the effect of the training program in developing the students' skills in teaching for thinking, the difference between the scores from the two observations, collected before and after training, was measured for each student, using the Wilcoxon test for repeated measurements on a single sample. (Corder \& Foreman, 2009)

5. The data shown in Table 2 indicates that there is a statistically significant difference at the 0.05 level between the two scores of the pre and post applications of the observation checklist for each subject of the sample in favor of the post application. 
Table 2. Wilcoxon Signed Rank Test for the Difference in the Factors between the Pre and Post Applications of the Observation Checklist

\begin{tabular}{|c|c|c|c|c|c|c|}
\hline Factor & Signed Ranks & $\mathrm{N}$ & $\begin{array}{l}\text { Mean } \\
\text { Rank }\end{array}$ & $\begin{array}{l}\text { Sum } \\
\text { Ranks }\end{array}$ & $\mathrm{of}_{\mathrm{Z}}$ & $\begin{array}{l}\text { Sig. } \\
\text { (2-tailed) }\end{array}$ \\
\hline \multirow{3}{*}{ Factor\#1 } & Negative Ranks & 0 & 0.00 & 0.00 & \multirow{3}{*}{-2.023} & \multirow{3}{*}{$\begin{array}{l}0.043 \\
(0.05)\end{array}$} \\
\hline & Positive Ranks & 5 & 3.00 & 15.00 & & \\
\hline & Ties & 0 & & & & \\
\hline \multirow{3}{*}{ Factor\#2 } & Negative Ranks & 0 & 0.00 & 0.00 & \multirow{3}{*}{-2.023} & \multirow{3}{*}{$\begin{array}{l}0.043 \\
(0.05)\end{array}$} \\
\hline & Positive Ranks & 5 & 3.00 & 15.00 & & \\
\hline & Ties & 0 & & & & \\
\hline \multirow{3}{*}{ Factor\#3 } & Negative Ranks & 0 & 0.00 & 0.00 & \multirow{3}{*}{-2.032} & \multirow{3}{*}{$\begin{array}{l}0.042 \\
(0.05)\end{array}$} \\
\hline & Positive Ranks & 5 & 3.00 & 15.00 & & \\
\hline & Ties & 0 & & & & \\
\hline \multirow{3}{*}{ Factor\#4 } & Negative Ranks & 0 & 0.00 & 0.00 & \multirow{3}{*}{-2.023} & \multirow{3}{*}{$\begin{array}{l}0.043 \\
(0.05)\end{array}$} \\
\hline & Positive Ranks & 5 & 3.00 & 15.00 & & \\
\hline & Ties & 0 & & & & \\
\hline \multirow{3}{*}{ Total } & Negative Ranks & 0 & 0.00 & 0.00 & \multirow{3}{*}{-2.023} & \multirow{3}{*}{$\begin{array}{l}0.043 \\
(0.05)\end{array}$} \\
\hline & Positive Ranks & 5 & 3.00 & 15.00 & & \\
\hline & Ties & 0 & & & & \\
\hline
\end{tabular}

Negative Ranks $=$ number of students who scored higher on pre application

Positive Ranks $=$ number of students who scored higher on post application

Ties $=$ number of students whose both scores are equal

\section{Discussion and Conclusion}

The findings and recommendations of researchers and specialists in thinking-based learning and teaching have stressed the importance of providing teachers with various methods and strategies for teaching thinking. The current research aimed at suggesting a program for developing skills in teaching for thinking of pre-service English language teachers to meet the pedagogical demands for cultivating thinking skills at every stage of the teaching and learning process. This program, which consists of various components that constitute a comprehensive integrative framework for a well-developed training program, is an attempt to fulfill the need reported in a number of studies for integrating training in thinking skills into teacher education programs. In the Stapleton study (2011) for example, teachers expressed strong support for the inclusion of critical thinking in the curriculum and convey a desire for training in how to teach it effectively. Reed (1998) also calls for incorporating teaching thinking skills into the curricula of teacher training programs as early and as intensely as possible, beginning with a student's first educational course. She believes that training faculty to integrate thinking skills into course content should not wait until teachers are already in the classroom and entrenched in didactic methods of teaching.

This research aimed at raising the awareness of the importance of the skills of teaching for thinking and the related teaching behaviors that English language teachers should possess. For this purpose, an observation checklist comprising certain teacher behaviors that invite, maintain, and enhance students' thinking in the classroom was developed as a basis for evaluating the teachers' performance in the light of such skills.

For pilot testing of the proposed program, it was tried out on a sample of five pre-service English language teachers whose teaching performance was then evaluated using the developed observation checklist. Although the sample for pilot testing was a small one, the results showed that the program proved to be effective in developing the teachers' skills of teaching for thinking in various ways:

1. The student teachers succeeded in using various teaching strategies and techniques that promoted their students' understanding of the content and enhanced their thinking abilities.

2. Such strategies provided the students with opportunities to engage in thinking processes and to provide thoughtful responses.

3. The student teachers showed interest and enthusiasm in employing a variety of teaching strategies and techniques in their teaching of the different English language skills. 
4. They also developed skillful lesson plans that fostered thinking skills in their teaching and helped students to develop more effective ways to use their minds.

5. The teacher's role changed to facilitator of learning; therefore, the teachers recognized that they must focus on questioning and using thinking-based activities that stimulate their students to do their own thinking and to become more self-directed learners.

This result of pilot testing supports the findings reported by Al-Sudies (2005) in an EFL context. She found that training pre-service English language teachers to use the metacognitive awareness approach in their teaching with its processes - planning, monitoring, and evaluation-resulted in improvement in teaching writing skills. It has also reinforced the results of Alyamani (2004), who reported a significant development in science teachers' skills in teaching for thinking when they were trained using a program that aimed at developing the participants' skills of teaching for thinking.

Based on the above discussion, it can be concluded that this research could have contributed to the lack of literature in the field of developing the skills of teaching for thinking among English language teachers. It also suggests that adequate training in teaching for thinking is required for EFL teachers through a well-structured thinking program that incorporates various teaching methods and strategies to promote students' thinking in the classroom. A classroom observation checklist of teachers' behaviors that invite, maintain, and enhance students' thinking in the classroom should be considered as well as an effective instructional tool for evaluating EFL teachers' performance as a basis for developing their skills of teaching for thinking.

\section{References}

Al-Sudies, T. (2005). The effectiveness of metacognitive awareness approach on developing teaching writing skills for college students. Unpublished Doctoral Dissertation. Princess Noura University, Riyadh.

Al-Yamani, M. (2004). The effectiveness of a suggested program to train science teachers on the skills of teaching for thinking and their attitudes towards it. Unpublished Doctoral Dissertation. Girls College of Education, Princess Noura University, Riyadh.

Ary, D., Jacobs, L., Razavieh, A., \& Sorensen, C. (1996). Introduction to research in education. New York, NY: Harcourt Brace College.

Bataineh, O., \& Alazzi, K. (2009). Perceptions of Jordanian secondary schools teachers towards critical thinking. Retrieved from Education Resources Information Center. ERIC No. EJ869429.

Barell, J. (2001). A self-reflection on our own models of teaching. In A. L. Costa (Ed.), Developing minds (p. 551). Alexandria, VA: Association for Supervision and Curriculum Development.

Beyer, B. (2001). Teaching thinking skills: Defining the problem. In A. L. Costa (Ed.), Developing minds (pp. 35-40). Alexandria, VA: Association for Supervision and Curriculum Development.

Beyer, B. (2008). What research tells us about teaching thinking skills. The Social Studies, 99(5), 223. http://dx.doi.org/10.3200/TSSS.99.5.223-232

Brandt, R. (1984). Teaching of thinking, for thinking, about thinking. Educational Leadership, 42(1), 3.

Corder, G. W., \& Foreman, D. I. (2009). Nonparametric statistics for non-statisticians: A step-by-step approach. Hoboken, NJ: Wiley.

Costa, A. L. (2001a). Teaching for, of and about thinking. In A. L. Costa (Ed.), Developing minds (pp. 354-358). Alexandria, VA: Association for Supervision and Curriculum Development.

Costa, A. L. (2001b). Teacher behaviors that enable student thinking. In A. L. Costa (Ed.), Developing minds (pp. 359-369). Alexandria, VA: Association for Supervision and Curriculum Development.

Davidson, B., \& Dunham, R. (1996). Assessing EFL student progress in critical thinking with the Ennis-Weir Critical Thinking essay test. Retrieved from Education Resources Information Center. ERIC ED403302.

Field, L. W. (2001). Classroom observation checklist. In A. L. Costa (Ed.), Developing minds (pp. 552-554). Alexandria, VA: Association for Supervision and Curriculum Development.

Fisher, A. (2007). Critical thinking: An introduction. Cambridge, England: Cambridge University Press.

Hyerle, D. (2000). A field guide to using visual tools. Alexandria, VA: Association for Supervision and Curriculum Development.

Innabi, H., \& El Sheikh, O. (2007). The change in mathematics teachers' perceptions of critical thinking after 15 years of educational reform in Jordan. Retrieved from Education Resources Information Center. ERIC No. EJ748199. 
Joyce, B., \& Showers, B. (1980, February). Improving in-service training: The message of research. Educational Leadership, 37(5), 379-385.

Martin, D. S., \& Michelli, N. M. (2001). Preparing teachers of thinking. In A. L. Costa (Ed.), Developing minds (pp. 111-117). Alexandria, VA: Association for Supervision and Curriculum Development.

National Council for Accreditation of Teacher Education (NCATE). (2008). Professional standards for the accreditation of teacher preparation institutions. Retrieved on April 2009 from http://www.ncate.org/LinkClick.aspx?fileticket $=$ nX43fwKc4Ak\%3d\&tabid $=474$

Ong, A. (2006). Implementing a thinking curriculum. In A. C. Ong, \& G. D. Borich (Eds.), Teaching strategies that promote thinking: Models and curriculum approaches (pp. $\mathrm{xx}-\mathrm{xx}$ ). Shanghai, China: McGraw-Hill Education.

Paul, R., Elder, L., \& Bartell, T. (1997). California teacher preparation for instruction in critical thinking: Research findings and policy recommendations. Sacramento, CA: California Commission of Teacher Credentialing.

Perkins, D. (2008). Knowledge music (foreword). In R. Swartz, A. Costa, B. Beyer, R. Reagan, \& B. Kallick. Thinking-based learning: Activating students' potential (pp. xx-xx). Norwood, MA: Christopher-Gordon.

Piaget, J. (1971). Genetic epistemology. (E. Duckworth, Trans.). New York: W. W. Norton \& Company.

Prawat, R. S. (1991). The value of ideas: The immersion approach to the development of thinking. Educational Researcher, 70(2), 3-10. http://dx.doi.org/10.2307/1176828

Reed, J. (1998). Effect of a model for critical thinking on student achievement in primary source document analysis and interpretation, argumentative reasoning, critical thinking dispositions and history content in a community college history course. PhD Dissertation. College of Education, University of South Florida.

Renner, C. E. (1996). Enrich learner language production through content based instruction. Retrieved from Education Resources Information Center. ERIC No. ED 411694.

Rojas, V. P. (2001). A view from the foxhole: Elevating foreign language classrooms. In A. L. Costa (Ed.), Developing minds (pp. 326-331). Alexandria, VA: Association for Supervision and Curriculum Development.

Routman, R. (1994). Invitations: Changing as teachers and learners K-12. Portsmouth, NH: Heinemann.

Sokol, A., Oget, D., Sonntag, M., \& Khomenko, N. (2008). The development of inventive thinking skills in the upper secondary language classroom. Thinking Skills and Creativity, 3(1), 34.

Stapleton, P. (2011). A survey of attitudes towards critical thinking among Hong Kong secondary school teachers: Implications for policy change. Thinking Skills and Creativity, 6(1), 14.

Swartz, R. J. (2001). Infusing critical and creative thinking into content instruction. In A. L. Costa (Ed.), Developing minds (pp. 266-274). Alexandria, VA: Association for Supervision and Curriculum Development.

Swartz, R., Costa, A., Beyer, B., Reagan, R., \& Kallic, B. (2008). Thinking-based learning: Activating students' potential. Norwood, MA: Christopher-Gordon.

Thurman, B. (2009). Teaching of critical thinking skills in the English content area in South Dakota public high schools and colleges. Retrieved from Education Resources Information Center. ERIC No. ED513229.

Vygotsky, L. (1962). Thought and language. Cambridge, MA: The MIT Press. http://dx.doi.org/10.1037/11193-002

Wenglinsky, H. (2000). How teaching matters: Bringing the classroom back into discussions of teacher quality. Princeton, NJ: Educational Testing Service.

\section{Appendix}

Program Resources

Beyer, B. K. (1997). Improving student thinking: A comprehensive approach. Boston, MA: Allyn and Bacon.

Celce-Murcia, M. (Ed.) (2001). Teaching English as a second or foreign language. Boston, MA: Heinle \& Heinle.

Costa, A., \& Lowery, L. (1989). Techniques for teaching thinking. Pacific Grove, CA: Midwest Publications.

Costa, A. L. (Ed.). (2001). Developing minds: A resource book for teaching thinking. Alexandria, VA: Association for Supervision and Curriculum Development.

De Bono, E. (1990). Lateral thinking: Creativity step by step. New York, NY: Harper Perennial.

De Bono, E. (1993). Teach your child how to think. New York, NY: Penguin.

Fisher, A. (2007). Critical thinking: An introduction. Cambridge, England: Cambridge University Press. 
Freeman, Y. S., \& Freeman, D. E. (1998). ESL/EFL teaching: Principles for success. Portsmouth, NH: Heinemann.

Harmer, J. (2006). The practice of English language teaching. Harlow, England: Pearson Education.

Hedge, T. (2008). Teaching and learning in the language classroom. Oxford, England: Oxford University Press.

Norris, S. P., \& Ennis, R. H. (1989). Evaluating critical thinking. Pacific Grove, CA: Critical Thinking Books and Software

Ong, A. C., \& Borich, G. D. (Eds.) (2006). Teaching strategies that promote thinking: Models and curriculum approaches. Shanghai, China: McGraw-Hill Education.

Swartz, R., \& Parks, S. (1994). Infusing the teaching of critical and creative thinking into content instruction. Pacific Grove, CA: Critical Thinking Press and Software.

Swartz, R., \& Perkins, D. (1990). Teaching thinking: Issues \& approaches. Pacific Grove, CA: Critical Thinking Press and Software.

Swartz, R., Costa, A., Beyer, B., Reagan, R., \& Kallick, B. (2008). Thinking-based learning: Activating students' potential. Norwood, MA: Christopher-Gordon.

Zwiers, J. (2004). Developing academic thinking skills in grades 6-12. Newark, DE: International Reading Association. 